\title{
Using environmental conflict resolution and consensus building towards improved sustainability
}

\author{
J. J. Haydon \& J. Kuang \\ Environmental Dispute Resolution Foundation, Australia
}

\begin{abstract}
The resolution of environmental disputes and conflicts is an important component for long term sustainability in which diversity and well-being issues are considered. The authors combine science and law with diverse cultural backgrounds. Environmental rights and responsibilities are evolving through many processes which emphasise improved dialogue. This paper promotes a new paradigm where:

- Productivity has to be environmentally sustainable;

- Polarised debate is replaced with dialogue and facilitated information sharing;

- Active listening is practised as part of appreciating the underlying concerns of others;

- Diversity and well being should be taken into account in devising a "decision making model". The options are limitless but careful planning is important;

- Consensus building is recommended.
\end{abstract}

Individuals and communities benefit from a structured process for the resolution of environmental disputes. Sustainability is about sharing experiences and learning to develop improved techniques. Managing public participation is analysed as a technique for improving decision making processes. Diversity is a community asset. Intergenerational Equity is an essential principle. It helps guide the new decision making paradigm. The new paradigm for decision making extends to the implementation of new and improved environmental management processes. It is a partnership between Government, business, industry and individuals. Creative ways to solve problems allows innovation to thrive. What are the benefits of a third party (independent) facilitator? Facilitation is a broad 
concept so has the potential for a wide range of opportunities and outcomes. During the remainder of the $21^{\text {st }}$ century, we need to encourage a greater use of environmental conflict resolution, dispute minimisation, consensus building and collaborative governance techniques.

Keywords: sustainability, productivity, public participation, diversity, innovation, local government, conflict resolution, consensus building, facilitator.

\section{Introduction}

The resolution of environmental disputes and conflicts is an important component for long term sustainability in which diversity and well-being issues are considered. The authors combine science and law with diverse cultural backgrounds. Improved sustainability is best achieved through working together. Collaborations/partnerships between Government and business/industry and between Governments and the Non Government Organisations (NGOs) have a better chance of success than going it alone. This is achieved through the sharing of information and innovation. Goodwill helps but active listening is a more empowering part of the collaborative processes.

\section{A new paradigm: an improved participatory model}

Environmental rights and responsibilities are evolving through many processes which emphasise improved dialogue. Polarised debate is not as productive as dialogue where the sharing of information is enhanced. A consensus orientated approach is preferred. Productivity is typically a measure of economic growth. In a sustainability context productivity needs to be measured with good/improved environmental outcomes in mind. Linked to the environmental human right to a good/clean physical environment which recognises intergenerational equity, productivity improvements have the potential to be associated with the elimination of poverty as recognised by the United Nations (UN) and the raising of living standards (Wikipedia [1]). An inclusive consensus approach will lead to improved productivity through diversity and innovation. An improved involvement of the NGO sector (also known as Civil Society) will enhance the consensus building model leading to broader forms of participatory involvement. Individuals are more likely to get involved in sustainability issues if they can see the consensus building happening. They are not alone. Together we can make a more sustainable difference in our cities.

\subsection{Productivity in an environmentally sustainable way}

Harris [2] says For a productive economy, we need a continuous commitment to innovation; early adaptation to new technology; the regular updating of business process; removal of impediments to competitive entry; and a constant effort to upgrade skills of employees. Environmental public policy can and should be a major contributor towards productivity. Productivity improvements also increase a country's ability to finance education, public health, the environment and the 
arts (Wikipedia [1]). Atos Consulting and Technology Services [3] examine Doing more for less - the new productivity paradigm to identify three keystones. Firstly, reclaiming time lost to low-value activities to reduce the impacts arising from work having become more complex - in a sense of freeing up enterprises to do more. Secondly, a new approach to change where improvements through centrally-managed transformations are replaced with tactical improvements coordinated by a central team or driven by individuals where clear communications, commitment by senior management and involvement of people at all levels are the major components. The third keystone is harnessing new technology.

\subsection{Dialogue and facilitated information sharing}

Debating is an adversarial process whereas dialogue is an information sharing collaborative process in which new ideas and innovation get an improved opportunity of being discussed and developed. Implementation of new methodologies is improved as the parties to the dialogue "own" and respect the dialogue outcome resulting from their meaningful participation.

\subsection{Active listening}

This is a powerful mechanism which should not be underestimated. It involves empathy and seeks to understand the underlying concerns held by others. By actively listening opposing/disputing parties often find a way towards consensus. Wikipedia [4] says Active listening is a communication technique that requires the listener to feed back what they hear to the speaker, by way of re-stating or paraphrasing what they have heard in their own words, to confirm what they have heard and moreover, to confirm the understanding of both parties. When interacting, people often "wait to speak" rather than listening attentively. They might also be distracted. Active listening is a structured way of listening and responding to others, focusing attention on the "function" of communicating objectively as opposed to focusing on "forms", passive expression or subjectivity.

\subsection{Diversity and well being}

Diversity is part of an innovative approach to productivity through the constant flow of new and diverse ideas. It is wide enough to include learning from indigenous cultures, cultural and religious diversity, valuing of women and people of varying ages in the workforce, and encouraging the participation of people with disabilities. Diversity is a community asset based on respect for differences and a tolerance of different backgrounds. Looking at environmental issues through different eyes allows innovation to be suggested and through the active listening and the dialogue process common ground is explored as the parties work towards a consensus. In the context of sustainability "well being” is an environmental human right which comes from good physical environmental outcomes. 


\subsection{Consensus building is recommended}

Developing "common ground" is fundamental in the consensus building process. The negotiating parties need to get to know one another. Developing a relationship among the parties helps the negotiation. Even sharing a meal can be an important element in a negotiation. While technical (expert) input is essential public participation is also helpful. Local and indigenous knowledge are key elements in developing a consensus. Wikipedia [5] says Consensus decisionmaking is a group decision making process that seeks the consent of all participants. Consensus may be defined professionally as an acceptable resolution, one that can be supported, even if not the "favourite" of each individual. Consensus is defined by Merriam-Webster as, first, general agreement, and second, group solidarity of belief or sentiment. It has its origin in the Latin word cōnsēnsus (agreement), which is from cōnsentiō meaning literally feel together. It is used to describe both the decision and the process of reaching a decision. Consensus decision-making is thus concerned with the process of deliberating and finalizing a decision, and the social and political effects of using this process.

\section{Structured processes for the resolution of environmental disputes}

Individuals and communities benefit from a structured process for the resolution of environmental disputes. There is a need to develop dispute avoidance and conflict minimisation. For the remaining disputes there needs to be a greater use of third party facilitators. A structured process includes consensus building especially though dialogue rather than polarised debate. The facilitator helps the discussion process keep on track by using a number of techniques like objectivity and reality testing. Wikipedia [6] says A facilitator is someone who helps a group of people understand their common objectives and assists them to plan to achieve them without taking a particular position in the discussion. Some facilitator tools will try to assist the group in achieving a consensus on any disagreements that preexist or emerge in the meeting so that it has a strong basis for future action.

\subsection{Sustainability is about sharing experiences}

Sustainability is about sharing experiences and learning to develop improved techniques. Taking environmental sustainability as creating a balance between development and the environment the forms of participation will vary depending on the scope and location of the "project".

\subsection{The need for public participation}

Managing public participation is a technique for improving decision making processes. For example, before a public meeting a facilitator can discuss concerns in separate sessions with groups who have a common interest. The role 
of the facilitator at the public meeting is to keep the dialogue moving and maintaining civility. If a disruption occurs at the public meeting the opportunity for a separate sub-meeting to discuss the concerns allows the facilitator to help these conflicting parties to work out a way to return to and continue the public meeting.

\subsection{Interactive workshops}

The interactive workshop seminar style is proving to be a successful learning exercise when compared to the more traditional "talkfest" style for conferences. The two way dialogue helps the workshop facilitators as well as delegates. It assists in a constructive exchange of ideas.

\section{Intergenerational Equity is an essential principle}

Intergenerational Equity is an essential principle from the Brundtland Report (1987) and the Rio Declaration (1992). It guides the new decision making paradigm in helpful ways. The current generation looks at passing on the environment in a better shape than it was inherited - or, at least, in a no worse condition. The negotiators looking for solutions have the opportunity to consider the future generation including children and grandchildren which widens the scope of what can be decided.

\section{New and improved environmental management processes}

The new paradigm for decision making extends to the implementation of new and improved environmental management processes. Whilst continuing development is important to eliminate poverty it has to be environmentally responsible. There is no one particular model of community consultation and participation. What is important is that the process remains flexible and that the maximum opportunity to participate by relevant stakeholders is given. How the resources for that participation are marshalled and managed is a matter for the individual project to assess. Broad scale community consultation can occur first before the program is developed or alternatively the program is developed as a policy matter by a small but representative sample of the community. Then a public awareness program encourages the broader community to become involved in the implementation of the environmental program.

\section{Partnerships between government, business, industry and the community}

There needs to be partnerships between Government, business, industry and individuals. Broad community involvement helps get things done. In a true partnership there is "ownership" of a sustainability program/activity which is derived from the participatory model. The concept of a broad alliance of people, governments, civil society and the private sector, all working together to secure 
the future we want for present and future generations was recognised by Rio+20 together with sustainable development being inclusive and people-centred involving all people including youth, children and women [7]. It extends further to indigenous peoples and the elderly. Environmental Issues need to be looked upon as matters of community concern. Governments are part of the community, as are business, industry, non government organisations and individuals. It is important to note that governments cannot do it alone for two basic reasons. Firstly, the taxation resources of governments (collectively) are not at a sufficient level to be able to address all matters. Secondly, there is a wealth of knowledge outside government which will benefit the process, if it is accessed. For example, there is enormous experience and expertise within non government organisations that has been built up over a long period of time. That is a valuable community resource which should be involved in cooperative environmental measures. Likewise, business and industry has an important role to play in the contribution towards cooperative measures.

\subsection{Environmental responsibility}

Corporate environmental responsibility for business and industry is part of their social responsibility and is good for business. Individual environmental responsibility helps achieve better environmental outcomes. Empowering individuals, business and industry becomes part of building consensus. Individuals are important no matter where they find themselves within the community. Outstanding individuals (including business and industry leaders) can be found within all walks of life and it is important that they have a commitment to participation. By leadership individuals give to the general community arising the opportunity and the encouragement to participate. It is by example that other people will join in the participation process.

\subsection{Non Government Organisations (NGOs)}

The formation of NGOs helps create forums for constructive dialogue and consensus building as a form of community well being and aiding long term sustainability. The full participation of civil society is part of the common vision resolved at Rio+20 [7]. NGOs come in many different forms. They are professional groups and some are groups of interested individuals who have joined together for a common cause. All of them can provide a valuable resource in terms of gathering together important data of an environmental nature and generating ideas to improve sustainability. It is important to tap into all of these NGOs so that these resources become publicly available and able to be used by governments, business and industry.

\subsection{Governments}

Governments should be environmental leaders by legislating one rule for all (including Government) to follow. Secondly, Governments have the opportunity to create incentives for the implementation of environmental policies. Thirdly, 
Governments should allow for an improved form of public participation. Finally, Governments have the opportunity to respond creatively and in an environmentally positive way to suggestions from NGOs, business and industry. By undertaking these four suggestions there will be an improved dialogue among stakeholders and a reduced level of conflict. It will also provide a framework for resolving environmental disputes leading to improved sustainability.

\section{4 “Top down" and "bottom up"}

Both "top down" and "bottom up" approaches to environmental sustainability can be inspiring. Each demonstrates different forms of leadership. An individual city dweller can inspire other urban dwellers to adopt new techniques by practical example (like recycling). Senior management can inspire employee motivated environmental improvements. The governing body of the corporate entity (including governments) should be aware of and adopt an environmental policy for the organisation. This approach strengthens the corporate social responsibility.

\subsubsection{Bottom up}

Each individual is important and can make a contribution towards a sustainable city. Empowering local communities was recognised at Rio+20 (United Nations Conference on Sustainable Development 2012) in recommendation 3 of the Sustainable Cities and Innovation of the Sustainable Development Dialogues (the civil society forum at Rio+20) [8].

\subsubsection{Networking, innovation and equitable access to information}

Networking is recognised at Rio+20 for Sustainable Cities and Innovation part of the Sustainable Development Dialogues [8]. Recommendation 3 of the Sustainable Development for Fighting Poverty of the Sustainable Development Dialogues wants greater participation, representation and justice at local, national and international level decision-making including "grassroots innovation" [9]. In 1995 two environmental rights were discussed by Haydon [10] - the right to information and the right to participation as part of an informed approach to environmental issues.

\subsubsection{Agenda 21}

Nine major groups are recognised in Agenda 21 (1992) which is a non binding voluntary implemented action plan for sustainable development [11]. They are (1) Business and Industry; (2) Children and Youth; (3) Farmers; (4) Indigenous Peoples; (5) Local Authorities; (6) NGOs; (7) Scientific and Technological Community; (8) Women; and (9) Workers and Trade Unions [12]. Since then Faith Groups and Elderly People have been added to the United Nations Environment Program's (UNEP's) stakeholders [13]. The broadest public participation and the active involvement of the non-governmental organizations and other groups should also be encouraged (Agenda 21 - Preamble in 1.3 [12]). 


\subsubsection{Top down}

Since the Stockholm Conference on the Human Environment in 1972 and the establishment of the United Nations Environment Program (UNEP) in 1972 the UN has continued a dialogue on environmental issues. Sustainable Development was defined by the Brundtland Report (1987) and has become the centre of ongoing international deliberations including, but not limited to, Rio (1992); Rio+10 in Johannesburg (2002) and Rio+20 (2012). Leadership and commitment at the top are key elements in empowering all levels of activity below the international discourse. Communities are inspired by national leadership so the top down within nations assists. A collaborative and building consensus theme is discussed in A New Global Partnership: Eradicate Poverty and Transform Economies Through Sustainable Development (2013) [14] with We live in an age when global problems can best be solved by thousands, even millions, of people working together. These (stakeholder) partnerships can guide the way to meeting targets and ensuring that programmes are effective on the ground. Such groups are sometimes called 'multi-stakeholder partnerships'. They bring together governments (local, city, national), experts, CSOs (Civil Society Organisations), businesses, philanthropists, universities and others, to work on a single theme. These partnerships are powerful because each partner comes to the table with direct knowledge and strong evidence, based on thorough research. This enables them to innovate, to advocate convincingly for good policies, and thus to secure funding. They have the skills to apply knowledge of what has worked before to new operations, and to scale up promising ideas to reach large populations in many countries - 'implementation and scaling up'.

\subsubsection{Two way communications}

The international negotiations (nations up to international forums) should be supported by a dedicated community effort aimed at improving the sustainability of cities. National leadership is the communication conduit from international down and national up. Active listening by all participants (including governments) develops a new sense of trust and helps find "common ground" leading to a consensus action plan.

\section{Dynamic nature of consensus building}

Building consensus across diverse interests and groups is dynamic. Consensus building is a transformational tool that can be effectively used to work towards achieving better environmental outcomes. It is valuable in interest based negotiations and a primary mechanism for the negotiation of win-win agreements.

\subsection{Multiple issues and a multidisciplinary approach}

The environment is complex so many issues can arise for consideration of one project. It is through a consultative process where the multiple issues are discussed and solutions found. Environmental sustainability is the overarching 
consideration in the consensus building exercise. Negotiating for sustainability and working together often require a multidisciplinary approach.

\section{A local government inspiration example}

Bringing people, organisations and ideas together is an important tool in all Sustainable Cities. ICLEI Oceania - Local Governments for Sustainability (part of the International Council for Environmental Initiatives) [15] is the Regional Secretariat for Australia, New Zealand and Pacific Island Nations has hosted three conferences on Thriving Neighbourhoods in 2011, 2012 and 2013 in Melbourne, Australia [16].

\section{WHAT IS THRIVING NEIGHBOURHOODS?}

Thriving Neighbourhoods is a conference on emerging global approaches to the planning, design and management of communities and cities that are set to radically improve the sustainability, liveability, health, and productivity of communities.

Thriving communities have the resilience needed to adapt creatively to unexpected challenges such as climate change, population change, rapid technological change, social upheaval and economic crises.

The complexity of the systems involved in creating thriving communities poses difficult and challenging issues for planners, developers, managers and researchers. But the potential returns on the invested effort are massive.

Capturing these returns requires professional collaboration across policy sectors including health, planning, design, infrastructure, IT and the built and natural environments. Communities must also be engaged from the outset, recognising diverse cultural and individual needs.

Thriving Neighbourhoods is an initiative of ICLEI - Local Governments for Sustainability is the world's leading association of cities and local governments dedicated to sustainable development. ICLEI is a powerful movement of 12 mega-cities, 100 super-cities and urban regions, 450 large cities as well as 450 small and medium-sized cities and towns in 84 countries. ICLEI Oceania is the Regional Secretariat for Australia, New Zealand and Pacific Island Nations.

This is an example of how to engage communities at neighbour and/or city level where actions are undertaken not only by Governments but also by NGOs (Non Government Organisations otherwise called Civil Society) and a range professionals from a wide range of disciplines (e.g. architecture, community arts, engineering, recreational planning, town planning and urban design). A five pillars approach was taken for Creating Thriving Neighbourhoods in 2013. (http://thrivingneigbourhoods.blogspot.com.au/)

\section{Conclusions: a greater use of various techniques}

In the $21^{\text {st }}$ century, we need to encourage a greater use of environmental conflict resolution, dispute minimisation and avoidance, consensus building and collaborative governance techniques. Red tape is reduced. It is inevitable that 
Table 1: Adapted from the overarching guide of the Thriving Neighbourhoods Conference 2013.

\begin{tabular}{|l|l|l|l|l|}
\hline \multicolumn{3}{|c}{ CREATING THRIVING NEIGHBOURHOODS: THE PILLARS } \\
\hline $\begin{array}{l}\text { Leadership } \\
\text { and } \\
\text { Government }\end{array}$ & Innovation & $\begin{array}{l}\text { Environmental } \\
\text { imperatives }\end{array}$ & $\begin{array}{l}\text { Economic } \\
\text { needs }\end{array}$ & $\begin{array}{l}\text { Social } \\
\text { needs }\end{array}$ \\
\hline $\begin{array}{l}\text { community } \\
\text { sustainability } \\
\text { champions } \\
\text { and } \\
\text { advocates }\end{array}$ & creativity & conservation & productivity & $\begin{array}{l}\text { social } \\
\text { participation }\end{array}$ \\
\hline $\begin{array}{l}\text { industry } \\
\text { early } \\
\text { adoption of } \\
\text { the principles } \\
\text { of thriving } \\
\text { communities, } \\
\text { corporate } \\
\text { social } \\
\text { responsibility }\end{array}$ & $\begin{array}{l}\text { technology, } \\
\text { design }\end{array}$ & natural systems & $\begin{array}{l}\text { jobs, } \\
\text { business }\end{array}$ & culture \\
$\begin{array}{l}\text { policy, } \\
\text { regulation } \\
\text { and } \\
\text { incentives }\end{array}$ & $\begin{array}{l}\text { organisational } \\
\text { systems }\end{array}$ & $\begin{array}{l}\text { climate change } \\
\text { management }\end{array}$ & $\begin{array}{l}\text { people's } \\
\text { aspirations }\end{array}$ & health and \\
wellbeing
\end{tabular}

conflicts will arise. Once a conflict arises the sooner it is referred to a dispute resolution process the better as it avoids escalation. Haydon and Kuang [17] have developed an 8 point plan towards achieving better environmental outcomes.

\subsection{Dispute minimisation and avoidance}

Better facts and research leads to fewer disputes. For example, where there is a common basis for assessing particular projects including safeguards by way of conditions if the regulatory agency decides to approve. As more knowledge and understanding of ecological processes become known and accepted then Governments, Business, Industry and the NGOs "respect" a code of conduct for the handling of the particular issue. For example, as we understand more about the science of climate change projects will be expected to respond with appropriate adaptation methods. With better environmental knowledge there is an opportunity to avoid disputes. The community needs to focus on dispute avoidance as a mechanism. Accessibility to all relevant knowledge is fundamental to any consideration of dispute avoidance. There is a need for trust so that all relevant information is recorded and available for public access. A dispute minimisation focus helps manage and resolve the conflict. 


\subsection{Consultative arrangements}

Decision making needs to be more of a shared experience. Sometimes this can be a collaborative exercise and on other occasions the final decision maker is better informed from a variety of sources as to available options before the final decision is made. Many hybrids are able to be developed depending on the project and its location. Haydon and Kuang [17, 18] discuss aspects of the Environmental Law Roundtable of Australia and New Zealand (ELRANZ) including its Manual.

\section{References}

[1] Wikipedia - Productivity http://en.wikipedia.org/wiki/Productivity

[2] Harris P., Chairman, Productivity Commission (Australia), The productivity reform outlook PC Update, May 2013, (ISSN 1442-6671) http://www.pc.gov.au/about-us/pc-update

[3] Atos Consulting and Technology, Doing more with less - the new productivity paradigm http://www.uk.atosconsulting.com/en-uk/business_ insights/points_of_view/doing-more-for-less-the-new-productivityparadigm/default.htm

[4] Wikipedia - Active Listening http://en.wikipedia.org/wiki/Active_listening

[5] Wikipedia - Consensus decision-making http://en.wikipedia.org /wiki/Consensus

[6] Wikipedia - Facilitator http://en.wikipedia.org/wiki/Facilitator

[7] Rio+ 20: Report of the United Nations Conference on Sustainable Development, 2012, A/CONF.216/16

[8] Rio+20: Sustainable Development Dialogues - Sustainable Cities and Innovation, 2012, http://www.uncsd2012.org/index.php?page=view\&type $=1015 \& n r=10 \& m e n u=23$

[9] Rio+20: Sustainable Development Dialogues - Sustainable Development for Fighting Poverty, 2012, http://www.uncsd2012.org/index.php?page $=$ view \& type $=1015 \& n r=4 \&$ menu $=23$

[10] Haydon, J.J., The Continuing Development of the Right to Know and the Right to Participate as Public Environmental Rights presented to the Queensland Environmental Law Association Conference, Port Douglas, Australia, 1995 - copy available from johnhaydon@ecodirections.com

[11] Wikipedia - Agenda 21 http://en.wikipedia.org/wiki/Agenda_21

[12] United Nations Sustainable Development: Agenda 21, 1992, http://sustainabledevelopment.un.org/content/documents/Agenda21.pdf

[13] UNEP Perspectives Issue No 2, January 2012, Models for Local Government Organisations (LGOs) involvement in a strengthened UNEP http://www.unep.org/civilsociety/Portals/24105/documents/perspectives/ENVIRONMENT_PAPERS _DISCUSSION_2.pdf

[14] UN Secretary General's High Level Panel of Eminent Persons on the Post2015 Development Agenda, A New Global Partnership: Eradicate Poverty 
and Transform Economies Through Sustainable Development, May 2013, http://www.un.org/sg/management/pdf/HLP_P2015_Report.pdf

[15] ICLEI Oceania - Local Governments for Sustainability (Australia, New Zealand and Pacific Island Nations), Melbourne, Australia http://archive.iclei.org/index.php?id=1149

[16] Thriving Neighbourhoods http://www.thrivingneighbourhoods.org and http://thrivingneigbourhoods.blogspot.com.au

[17] Haydon J.J and Kuang J., Developing and Expanding the Environmental Conflict Resolution Toolkit: Facilitation and Consensus Building for Better Environmental Outcomes presented to the 2011 International Conference on Environmental Science and Development (ICESD 2011) in Mumbai, India, January 2011 - copy available from johnhaydon@ecodirections.com

[18] Haydon J.J and Kuang J., Aspects of Environmental Conflict Resolution and Consensus Building for Improved Sustainability Outcomes presented to the 2012 Second Asian Conference on Sustainability, Energy and the Environment (ACSEE 2012) in Osaka, Japan, May 2012 - copy available from johnhaydon@ecodirections.com 